\title{
Procrastination Attitude of the Senior High School Students in Modular Distance Learning Modality
}

\author{
Gel Marie B. Tiboron ${ }^{1}$, Dr. Ronald S. Decano ${ }^{2}$, Mark Van M. Buladaco ${ }^{3}$ \\ ${ }^{l}$ Graduate Student, Doctor of Philosophy in Educational Management, Davao del Norte State College \\ ${ }^{2}$ Dean, Institute of Advanced Studies, Davao del Norte State College \\ ${ }^{3}$ Dean, Institute of Computing, Davao del Norte State College
}

\begin{abstract}
Nowadays, especially in modular modality, students tend to procrastinate or to delay a certain work that needs to be accomplished on a certain deadline. It is a behavioral problem that occurs in every individual. The research design of this study utilized the phenomenological method to determine the Procrastination attitude of the students in a modular distance learning modality in The Rizal Memorial Colleges, Inc. The participants of this study composed of 10 Senior High School students. The data obtained identified emergent themes clustered into three, namely: Diligence, Honesty, and Hope. Based on the results, one of the existing behaviors that any person could have, with or without their knowledge, and became the major problem of everyone, especially to every student, is procrastination. With this, the implications to the teachers were to provide motivations towards their students in order to banish procrastination.
\end{abstract}

Keywords: procrastination, behaviors, cramming, attitude, senior high school

\section{INTRODUCTION}

$\mathrm{P}$ rocrastination is a bad habit that needs to be unleashed. It is prevalent as to everyone do this bad practice. This irrational delay relates to increased stress levels, frustration, anxiety, and it lowers the level of creativity and productivity of a student.

Students procrastinate; they were cramming, and it is expected that the procrastinators will be facing negative consequences. Especially this study look forwards to the School opening will not necessarily mean traditional face-toface learning in the classroom.

The physical opening will depend on the risk severity grading or classification of a certain community pursuant to guidelines from the Department of Health (DOH), the Inter-Agency Task Force (IATF) for the Management of Emerging Infectious Diseases in the Philippines, and the Office of the President (OP). This phenomenon becomes problematic as students make this bad behavior a habit. That is why the researchers tend to dig deeper investigation on this problem to share and expose students' sentiments towards procrastination attitude of students in modular distance learning modality. Teachers wanted to express their different experiences on this matter and know and share their strategies on surpassing this kind of problem.

People tend to delay things even if they know that it has many negative consequences to face. This bad behavior becomes a habit of everyone. As people neglect things that need to be done soon, they have this practice of cramming, and the root cause of it is procrastination. This kind of irrational behavior can have a huge impact on one's life. Being engaged in this kind of habit can lead to serious mental health problems. Procrastination relates to stress, anxiety, or worse, depression.

In the global context, Head of the American Psychological Association's Center for Organizational Excellence, Ballard (2018), said that procrastination is not all about the avoidance of tasks. Still, it should include an aspect that is irrational, inimical, and irrelevant.

However, according to Ducharme, as cited from Rozental (2018) stated that people procrastinate due to reason that they don't value a certain task, and they expect that they could not attain the value that they want to aim for because of the impulsivity of people. They commit procrastination because they are worried about the result and do not think that they can do well because they are scared to fail.

Bailey (2017) suggested that it would be easy if you continue what you have started. It will be better if you are going to finish the tasks right away. There would be no room for cramming if we will just do everything on time. The creativity, the beauty of the work you are making, the eagerness to make your work done, etc., will go away as long we will still practice procrastination.

Cherry (2019) added that neglecting a project or work, not doing tasks in school, or not doing the household chores, and the reason was because of the uncontrolled habit of procrastination, can absolutely give you a huge impact on your work, academic grades, and in your life, it is either gaining low grades or being fired to work.

Leiberman (2019) has proposed that the answer as to why doing procrastination makes us feel so rotten is due to consciousness within ourselves because whenever people procrastinate, they are not just aware that they are avoiding a task but doing it intentionally is not a good idea and yet they still do it.

In addition, Laureta (2017) stated that procrastination makes us loathe ourselves and regret not being productive early before, especially when facing loads of works and in need to meet the deadlines. Moreover, she said that there are ways to 
avoid procrastination, and those are to divide your works into parts, set personal deadlines, face the big waves first, and start something or anything.

The study has reported that procrastination can be the cause of having a fear of failure. Fear of failure is somewhat related to low self-confidence, where individuals delay tasks because of fear or belief that they will not succeed. Students with high confidence can somehow respond positively to academic challenges despite the difficulty of work. On the other hand, task evasiveness is characterized by dislike of activities and anxiety, which leads to procrastination.

\section{Related Literature}

\section{Procrastination Attitude of Students}

Plaxton (2017) reported that many students treated procrastination as the worst hindrance when managing their time because they would prioritize the thing they revel in over their work. Some students have so many schedules, including school, homework, household chores, social life, and/or other extracurricular activities. Because of this, homework and schoolwork are frequently neglected, and they will do something more enjoyable to allow them to have extra freedom in the rest of their schedule.

However, Swanson (2016) reported that almost all of the researchers have considered procrastination largely as a failure of self-regulation, like terrible behaviors that have to do with a lack of self-control, such as overeating, and gambling problem, or overspending. Even though it is no longer counted as being lazy or having poor time management, many clever people who are procrastinating still become successful.

As Kent (2016) said, students begin to have interaction in routine avoidance behaviors, to the disapproval of their teachers. As a result, some students have trouble budgeting their study time, attending after-school greater help or workplace hours, and spending a long way less time than they at the start supposed to spend on their studying. This behavior is often sure up in a cram of emotions and confusion, leaving students thinking about what to tackle first. Although procrastination is regularly seen as a terrible phenomenon, some students record that it helps their educational performance.

\section{Mañana habit}

The Mañana habit, which is also known in Filipino as "Mamaya na" practice, is a Filipino term for procrastination. (Mejia, 2017) This kind of practice has already been an existing problem since before. And it was the reason why this kind of phenomenon is rapidly scattered through generations.

The students who procrastinate often have worse performance in any activity because postponing tasks will lead students who procrastinate to submit unfinished work and missed important deadlines. This means that procrastinators tend to earn worse grades than non-procrastinators, which becomes more problematic since some side effects can increase students' tendency to procrastinate more.

According to Katz, Eilot and Nevo, (2014), many students procrastinate with regards to lecture things to do (as cited from Steel, 2007). Procrastination involves delaying the performance and tasks until a person experiences distress due to having no time left to do works.

Furthermore, Gunn (2019) stated that students who procrastinate might be because they have a lack of motivation, low self-esteem, atychiphobia, trouble understanding, low energy levels, and poor organization skills. Students often procrastinate because they don't see how a project is relevant or important to them, don't understand the material, or just don't know how to get started.

Hence, Shangkuan (2019) suggested that many students need insights but. Lag in official work, which controls a person's goal-directed behavior. The official work is the capacity to expect issues, set objectives, arrange, organize, prioritize, delay satisfaction, screen advance and move in the event that essential, all of which are the cure to procrastination.

\section{Cramming}

Karafiloski (2018) has stated three (3) strategies to overcome procrastination in line with what has just been stated. Primarily, it is important to do your morning routines. Secondly, do it right now and pass it on to the actual deadline. Lastly, discipline yourself. You should always know what you need to do. You need to be focused and to work smarter and not harder.

However, when you feel like you don't want to do things, take some tiny steps to achieve your goal (Guagliardo, 2018). It is impossible to do all the loads at the same time. Just take it easy, small steps can still go farther, and we must put in our minds that whatever we do, we will just keep on moving forward and never stop. Having plenty of time to do works does not mean that we will just make it when the deadline is near or practice procrastination. We must work for it, littleby-little, in order to finish it smoothly, in the absence of cramming.

Also, focus on the reward that you would get after you finish the tasks. Be optimistic in everything you do and surround yourself with positive vibes (Hueber, 2018). It is very important that we must have motivation in doing things, for that will serve as the biggest factor to finish the work with effort and passion.

Another technique to overcome procrastination is to make a hard-scheduled deadline for yourself as if your boss gave it to you and then honor it the same way as your boss would wait for you to finish the task, as proposed by (Boitnott, 2018). Simple things bring big changes.

\section{Mannerism}

Mannerism is a distinctive behavioral trait. It is, so to say, an exaggerated, affected, situationally controlled style or habit in 
body language as well as in verbal behavior. The mannerisms of different contexts and social set-ups are designed and practiced according to socio-cultural, situational, and personal patterns and dispositions. Suitable mannerisms sometimes help professionals to be adorable among the people than others who cannot fine-tune this in themselves. Like other professionals, for teachers in this context, it is presumed that regulated and well-practiced formal classroom mannerisms and verbal behavior can lead to a major part of success in teaching. Especially, in Dorneyi (2018) words, the teacher's own behavior' is 'the single most important motivational tool' in the language classroom.

\section{Modular Distance Learning Modality}

There is a very significant connection between priorities and responsibilities. According to Croyle (2017), he has defined the relationship between responsibility and priority, as "responsibility is what is required, and priority is when it's required." Every student should invest more in education. Welvaert (2018) defined education in two ways. Education as an investment good which he coined that education is the best investment a person can have in his/her life and choosing a course that has a higher percentage of demand in the future would make the investment more worth it, and education as a consumption good in which you gain knowledge and satisfaction about yourself. He also proposed that education is an investment in which the return in the future is assured.

There is a purpose why a student should go to school and study hard. Reyes (2017) believed that it is not only the knowledge that a person can get from school, but studying hard can help a person to discover what is hidden within $\mathrm{him} / \mathrm{her}$ and to develop it along the way. Studying hard means investing for your future (Reyes, 2017; Welvaert, 2014), and it can help an individual to gain the skills he needs to acquire. Being able to study hard is another way for a person to discover his/her "strengths and weaknesses," which is very important for a person to be able to figure out on what field he/she is good at and what fields that are not suitable for the skills he/she has possessed. The main reason why a person should study hard is to contribute to changing the world and knowing that school is a training ground for the real world to come.

On the other hand, a study that opposed the term "study hard," Loveless (2019), proposed an idea that a person should study smarter and not harder. He also introduced different ways on how to do smart studying. A person must set a plan for his goals in studying and must practice a daily routine of studying. A person must follow what he needs to do according to the plan set; a person must not procrastinate in following what is planned for, resulting in cramming, which must be avoided. Loveless believes that cramming or being at the point of rushing something is the main reason why many errors occur. Thus, having a constant schedule for studying can lessen the probability of cramming. He also added that reading and reviewing notes could help improve a person's ability to remember all the lessons that have just been taught and enable a person to make his/her assignments correctly.

\section{Time Management}

Time management is the key to overcome procrastination. Controlling time and how to spend it wisely can be learned. You should make a list to follow what things are needed to be done. Know your priority, decide what you need to do first and what you need to do next, and so on. You should know how long it takes to finish your task. Do not do procrastinate. Do not delay a task, just focus on your to-do list that was written on your notepad. Be persistent on your task. Just keep doing what you are doing. Also, always check your progress; it keeps you on track to get everything complete. Be optimistic about everything you do. Always think the bright side. It is better that you have tried than never. (Rios, 2016)

This context presents how the distance learning course designers have rationalized the sophistication of their program, given the physical barriers of time zone management. For instance, situated in the extreme was synchronous discussion forum sessions, which are extended as asynchronous discussions. On the other hand, adopts both formal and informal synchronous tools to improve social interactions (Fulford and Zhang, 2017). This is justified by the low level of time management problems and physical barriers associated with time zones. The survey of learners in each of the case studies indicates their preferences not to be isolated and to be engaged with co-learners and tutors. This was mainly evident, where the students had to work on a group project as one of their assessments in the program. They understood the important role that time management-based delivery mechanisms played, but at the same time, appreciated the flexibility aspect of distance learning courses as the majority of the learners were employed full-time in the learning process (Fulford and Zhang, 2017).

The results show that amidst physical barriers such as difficulties of time zone management, the managers of distance learning programs still put in place mechanisms to facilitate social interactions as they considered them as priorities. The managers also want to ensure that they do not compromise the distance learning philosophy of learners studying in their own time and at their own pace by introducing too many synchronous delivery mechanisms (Ham and Davey, 2015).

\section{Theoretical Lens}

To have a clearer understanding of this matter, a brief discussion about the following approaches will be given by the researcher in accordance with the theoretical work of Siaputra (2010). Sigmund Freud coined psychoanalytic and psychodynamic approaches. He tried to explain the tendency of procrastination based on the concept of avoiding a task because of a threat to the ego. According to him, whenever the ego detects any kind of threat, the natural defense mechanism will occur, and which will probably result in 
avoidance of doing the task. On the other hand, the behavioristic approach stated that the repeated individuals' success raises procrastination despite having procrastinating behavior. This is due to the reason that there is a lack of punishment occurring about this kind of practice.

Furthermore, this approach is simply talking about a redundant occurrence of success despite having a practice of procrastination, and this scenario will continue as long as there is still no punishment for such procrastinators. Meanwhile, the cognitive approach proposed procrastination as an emotional disorder that was rooted in irrational thinking. In other words, this refers to positive thinking without doing anything. Or just simply means that you have the aim to do something, but you do not want to take any action for it.

\section{METHODOLOGY}

\section{Research Design}

Qualitative research, phenomenological approach was selected as the research approach for this study to focus on the commonality of a lived experience within a particular group or individual. The fundamental goal of the approach based on (Creswell 2013) is to arrive at a description of the nature of the particular phenomenon. The researcher would like to determine the Procrastination attitude of the Senior High School Students of The Rizal Memorial Colleges, Inc.

\section{Research Locale and Sampling}

The participants of this study were chosen via the Purposive sampling technique. This sampling method requires researchers to have prior knowledge about the purpose of their studies to properly choose and approach eligible participants. Ten (10) students who met the criterion were selected. These criteria play a vital role in choosing the right participants for the study, for it gives bases on how reliable and credible the study would be. This study will be conducted in a private school in Davao City, The Rizal Memorial Colleges, Inc. The school is strategically located at RMC Buildings, Purok 5, Lopez Jaena \& F. Torres Streets, Barangay 8-A Poblacion District, Davao City.

\section{Data Collection Procedure}

Thematic Content Analysis was used in interpreting the responses made by the key participants in determining the presence and experiences of the Senior High School Students on Procrastination. Their responses were processed and conducted through analysis. Transcripts were coded in considerable detail, with the focus shifting back and forth from the key claims of the participants to the researcher's interpretation of the meaning of the responses and subjectively interpreted. Meanwhile, the notes that will be obtained from the in-depth interview will be transcribed immediately. The researcher will be looking for common themes that will be found among the responses to each question. In this phase, the researcher will use thematic analysis in analyzing the gathered data.

\section{RESULTS AND DISCUSSIONS}

This section presents the results of the data gathered from the In-depth Interview with the participants. It aims to interpret all the data, analyze logically, discuss the things discovered, and compare the result to the existing studies related to this research.

The data obtained identified emergent themes clustered into three (3), namely: Diligence, Honesty, and Hope; it follows the researcher's chosen Filipino values as a theme. Each of the clustered themes also has essential Themes. In the first clustered theme, three (3) identified essential themes: Commitment, persistence, and responsibility. While in the second clustered theme, there are three (3) identified essential themes, namely: Accuracy, Perseverance, and Integrity. And lastly, for the third clustered theme, there are three (3) essential themes, namely: Fortitude, Time-Management, and Motivation.

\section{Implications for Future Direction}

One of the existing behaviors that any person could have, with or without their knowledge, and became the major problem of everyone, especially to every student, is procrastination. When a person procrastinates, it leads to cramming. And doing a task in a short period destroys one's creativity and productivity. Because every time that there's cramming, pressure and frustration eat our minds, including stress, guilt, anxiety, and worse, it leads to a serious mental illness which is depression. Many students have this irrational behavior, and it became their habit. They have this mindset that doing procrastination is good and advantageous for them. When in fact, it's absolutely not. This bad habit became a hindrance to students' achievements and goals. And this problem is very rampant here at Rizal Memorial Colleges Inc., where students procrastinate due to the following reasons: Primarily (1) students delay a certain task due to distractions; (2) neglecting responsibility; (3) lack of focus and motivation.; They used procrastination as (4) a technique in making a task easier.

Students tend to procrastinate due to distractions, specifically social media, and online games. These are very common and pervasive nowadays. In this generation, technologies are evolving; we are all surrounded by the modernization of the world. Several students are much attached to this kind of thing because, according to them, it gives them pleasure and happiness. They don't want the word 'responsibility because it pressures them to the point that they procrastinate and cram. They don't want the idea of holding responsibility because they hold the world that they felt the heaviness of it. Others say they procrastinate due to a lack of focus and motivation. The absence of reasons to make a certain task on time is one reason why students were having a hard time enabling them to finish it. Another factor is if a student was out of focus, where students were unable to start anything and failed to finish their tasks due to too much thinking of other things that distracted and out of concentration. They also think of procrastination as good behavior. They make it a technique to 
do their tasks easier because they believed that they could do it all if they are physically and mentally relaxed. That's why they tend to do a task at the last minute of time, where their minds function very well.

Everyone has priorities. We have priorities at home, in school, and in our community. We define the word priority as something that must be dealt with first. Students have these priorities. However, they still procrastinate. For some reason, short-term happiness. They used the time given to them in making a task, doing other things like surfing on social media, mobile games, watching movies, reading fiction books, etc., just to divert their selves to the responsibilities assigned to them.

Procrastination has a huge impact on every individual. It is bad behavior that anyone could experience. Nowadays, procrastination becomes a habit for everyone, which is very wrong because it can do no good for everybody. This bad practice needs to be stopped. There are three (3) main strategies on how to surpass procrastination: (1) First, students should have time management; (2) A healthy diet is a must; (3) Lastly, they should have motivations. Several students don't know how to manage their time accurately. They don't know how to use it properly. That's why it is important to know how to divide their time on the things they need to do because many people nowadays are just wasting their time doing unnecessary things. They're just abusing their time for their own pleasure. It is also important to have a healthy diet to be physically and mentally fit. Another thing is that students need to have motivations in life to have reasons to keep going in everything they do.

\section{Future Directions}

Rmc Admin. The administrators of The Rizal Memorial Colleges, Inc. You should conduct a study about your students' well-being and behaviors to respond to this matter. As the administrators, you should create a rule of discipline that must be observable and strictly implemented to provide better and well-disciplined cream of the crops. Through this, procrastination will vanish, and well-determined students will rise.

Principal. The principal of the Integrated Basic Education Department (IBED) of RMC should impose guidelines and strict rules and regulations to discipline the students. Nowadays, students do not lack knowledge; they lack discipline. Furthermore, as a principal, you should conduct a study on applying different strategies to overcome this matter. Procrastination is very evident among students, and it should be resolved immediately.

Guidance Office Of The Prefect Of Discipline. The guidance office must be concern about this issue. Thus, the prefect of discipline should provide seminars for the students experiencing and have experienced procrastinating on their set of priorities. This seminar should have a lot of encouragement to the students, in which they will be able to realize that this kind of behavior is nothing but full of disadvantages. This must be called "How to Discipline Yourself?: A Seminar for Overcoming Procrastination" that proper discipline is a must for every student of The Rizal Memorial Colleges, Inc. (IBED). This seminar should also talk about time management and self-regulation.

Teachers. The Integrated Basic Education Department of RMC should provide motivations towards their students to banish procrastination. In this way, students will become motivated and can have the energy to do things on time.

Future Researchers. You must conduct a study on the different factors why a student is procrastinating to have a deeper understanding of this problem. You should study the difference between procrastination and laziness. And conduct a study on finding strategies to have prioritization instead of procrastination.

\section{ACKNOWLEDGEMENT}

I, Gel Mari B. Tiboron, would like to extend my heartful appreciation and gratitude to the following people who contributed immeasurably to the success of this piece of work. Dr. Ronald Decano, research adviser and the Dean of the Graduate School of Davao del Norte State College for his encouragement to finish this research. The panel examiners, for their constructive comment and suggestion that helped me in improving this manuscript well. To Prof. Mark Van M. Buladaco, my brother, for helping me finishing this paper for publication.

In addition, I would also like to thank my husband and kids for being my inspiration and to their support. To my family, friends, students who contributed greatly to make this manuscript possible within a limited time frame. Finally, and most importantly, I would like to thank Allah SWT for the guidance and power 1 to achieve this great goal.

\section{REFERENCES}

[1] Abi Bagnes, 2014, procrastination among students, (https://www.scribd.com/document/257003979/ProcrastinationAmong-High-School-Students-

docx?fbclid=IwAR05pcp2hJKysNZPsYHUb0aYoA6XYbeH26rOoBqdinCaicTwa-ccdEffIQ), Dec, 232019

[2] AlexM.Eduque,2017,TheYouthToday,https://news.mb.com.ph/20 17/02/17/the-youth-today), December 2, 2019

[3] Andrea Jessa D. Reyes, 2017, 9 Reasons Why You Should Study Hard,

(http://udyong.gov.ph/index.php?option=com_content\&view=arti cle\&id=9295\%3A9-reasons-why-you-should-study-hard5798\&catid=90\&Itemid=1267), December 1, 2019

[4] Becton Loveless, 2019, 10 Habits of Highly Effective Students, (https://www.educationcorner.com/habits-of-successfulstudents.html), December 1, 2019

[5] Boge, Dominic J., 2007, Understanding and Overcoming procrastination, (https://mcgraw.princeton.edu/understanding-andovercoming-procrastination), January 22, 2020

[6] Bowman, Jennifer Davis, 2018, Why Students Don't Do Their Homework - And What You Can Do About It, (https://www.teachthought.com/pedagogy/why-students-dont-dotheir-homework-and-what-you-can-do-about-it/), January 22, 2020

[7] Dianne M. Tice and Roy F. Baumeister, 2019, Longitudinal study of procrastination, performance, stress, and health, 
(https://www.taylorfrancis.com/books/e/9781315175775/chapters/ 10.4324/9781315175775-9), December 1, 2019

[8] Elizabeth Lombardo Ph.D., 2017, 11 Ways to Overcome procrastination,

(https://www.psychologytoday.com/us/blog/betterperfect/201703/11-ways-overcome-procrastination?amp), December 1, 2019

[9] Forbes Coaches Council, 2018, 10 Ways to Beat Procrastination and Get Things Done, (https://www.forbes.com/sites/forbescoachescouncil/2018/03/22/1 0 -ways-to-beat-procrastination-and-get-thingsdone/\#31ff56f12902), November 30, 2019

[10] Frank Sonnenberg, 2017, 12reasons why people procrastinate, (https://www.linkedin.com/pulse/12-reasons-why-peopleprocrastinate-frank-sonnenberg/?trk=mp-readercard\&fbclid=IwAR1AjJambAJyvvgoYIaFgltuoeWCRLfb81mEn6 xJ9vncL6JM5iPwqyi_rFY), Dec, 232019

[11] Gunn, Jennifer, 2019, Is It Student Laziness or Something More?, (https://education.cu-portland.edu/blog/classroomresources/academic-procrastination-anxiety/), January 22, 2020

[12] Ide Bagus Siaputra, 2010, Temporal Motivation Theory: Best Theory (yet) to Explain procrastination, (scholar.goodle.com), December 2, 2019

[13] Jen Corre, 2017, Breaking Away from Procrastination -How to Do it Right, (http://www.optimindseo.com/tag/overcomingprocrastination/), December 1, 2019

[14] John Croyle, 2014, Responsibility and Priority,(https://bmetro.com/responsibility-and-priority/16953/), December 2, 2019

[15] Jon Nastor, 2015, 5 simple strategies for beating procrastination once for

all,

https://www.entrepreneur.com/article/246403?fbclid=IwAR3ZIRx DOOkG_M9CpgfMaf6VEBLlgM0QVlmcghQLwUmK5ka9vCh8 GnpmoP4, Dec 23, 2019

[16] Lee-Chua, Quenna N., 2011, Dealing with Procrastination among Students, http://school-principal.blogspot.com/2011/06/dealingwith-procrastination-among.html?m=1, January 22, 2020

[17] Letham, Susan J., 2015, The Procrastination Problem, https://www.successconsciousness.com/guest_articles/procrastinat ion.htm, January 22,2020

[18] Meier, et al., 2016, "Facebrocrastination"? Predictors of using Facebook for Procrastination and its effects on student' well-being, https://www.researchgate.net/publication/304524704_Facebocrasti nation_Predictors_of_using_Facebook_for_procrastination_and_it s_effects_on_students'_well-being, January 22, 2020

[19] Mejica, Andrianna, 2017, How to stop 'Mañana' habit from taking over your life, (https://www.rappler.com/brandrap/health-andself/164909-stop-manana-habit-health-fitness), January 22, 2020

[20] Mieke Welvaert, 2014, Why Do We Study?,(https://www.infometrics.co.nz/why-do-we-study/), December 1, 2019

[21] Michael Eason, 2018, 3 Mindful Ways to Overcome procrastination, (https://ph.asiatatler.com/life/3-ways-stopprocrastination), December 1, 2019

[22] Newton, Paul, 2014, How to Overcome procrastination, (https://hvtc.edu.vn/Portals/0/files/635841505366235737how-toovercome-procrastination.pdf), January 22, 2020

[23] Pavlina, Steve, 2013, Overcoming Procrastination, (http://philcivilengineeringreviewtips.blogspot.com/2013/12/overc oming-procrastination.html?m=1), January 22, 2020

[24] Piers Steel and Cornelius J. Konig, 2006, Integrating Theories of Motivation, (scholar.google.com), December 2, 2019

[25] Queena N. Lee-Chua, 2014, Rethinking Procrastination, (https://newsinfo.inquirer.net/642943/rethinking-procrastination), December 1, 2019

[26] Regan Collins, 2017, Top 10 Ways to Avoid procrastination, (https://www.collegexpress.com/articles-and-advice/majors-andacademics/blog/top-10-ways-avoid-procrastination/), December 1 , 2019

[27] Rufino Rios, 2016, Managing Time Effectively, (https://www.philstar.com/the-freeman/cebu- lifestyle/2016/06/22/1595490/managing-time-effectively), December 1, 2019

[28] Sayee Deshpande, 2018, 10 Reasons Why Household Chores Are Important, (https://1 specialplace.com/2018/01/25/importancehousehold-chores/?v=a25496ebf095), December 2, 2019

[29] Uy, A. R. (2020). "Blended Learning" In Virus-Hit Philippines. The ASEAN posts reserved 2020.

[30] Wagler, R. (2011). The Impact of Vicarious Experiences and Field Experience Classroom Characteristics on Preservice Elementary Science Teaching Efficacy

[31] Zenon, E. M. (2006). A Study of the Correlation Between Internet Access and

[32] Academic Achievement, and Internet Use and Academic Achievement, in Middle School Students.

[33] Vaiana, Dominic, 2019, How to stop Procrastinating: The only guide you'll ever need, (https://collegeinfogeek.com/how-to-stopprocrastinating/), January 22, 2020

[34] Weimer, Maryellen, 2009, Why students procrastinate and what can you do about it, (https://www.facultyfocus.com/articles/course-design-ideas/whystudents-procrastinate-and-what-you-can-do-about-it/), January 22,2020

[35] Wray, Maggie, 2014, 12 reasons why do students procrastinate....and what can you do about it?, (https://creatingpositivefutures.com/12-reasons-why-studentsprocrastinate/), January 22, 2020

[36] Zwilling, Martin, 2017, 8 Ways to Cure Your Procrastination Habit, (https://www.inc.com/martinzwilling/are-you-always-missing-deadlines-dontprocrastinate.html), January 23, 2020 